\title{
Anti-fertility effect of three inorganic salts against land snail, Massylaea vermiculata, (O.F. Müller1774) and their field efficiency
}

\author{
Soha A. Mobarak ${ }^{*}$ (1)
}

\begin{abstract}
Background: The ovotestis gland (the hermaphrodite gland) is a reproductive system organ that affects fertility of land snails. Thus, the present study was conducted to evaluate the effect of three inorganic salts (sodium carbonate, sodium benzoate, and sodium nitrate) against the land snail, Massylaea vermiculata under laboratory and field conditions. Snails were treated with serial concentrations of the tested salts for seven days using thin-layer film technique. The $L C_{50}$ of each salt was determined, and the effect of $1 / 2 L C_{50}$ of each was tested on egg-laying. In addition, $L P O$ enzyme was determined, and the histological effect of the ovotestis gland was inspected. The field efficiency of sodium carbonate and sodium nitrate were evaluated as a spray for 21 days on pomegranate nursery trees at Giza Governorate. The effects of inorganic salts were compared with methomyl (the compound recommended by the Egyptian Ministry of Agriculture against land snails in the field).

Results: The laboratory results revealed that sodium carbonate and sodium nitrate were more toxic than sodium benzoate, whereas the $\mathrm{LC}_{50}$ were $2.4,9.6$, and $11.8 \%$ for the three inorganic salts, respectively. Sodium carbonate and sodium nitrate achieved complete inhibition for egg production, while sodium benzoate gave $37.7 \%$ compared to 96.8\% for hatchability control. Sodium carbonate and sodium benzoate exhibited significant effect on LPO enzyme, while a non-significant effect was recorded by sodium nitrite compared with control. Regarding the histological effect, sodium carbonate and sodium nitrate had the same effect on ovotestis, as a necrobiotic change was observed in the ova, and diminishing in spermatozoal concentration, while sodium benzoate caused decreasing in spermatozoal concentration without any alteration in the ovarian compared with control. Regarding the field results, sodium carbonate and sodium nitrate achieved 78.4 and $79.0 \%$ reduction in land snail populations, respectively, compared with $75 \%$ for methomyl compound.

Conclusions: The tested inorganic salts have highly toxic effect against the land snail, M. vermiculata, and they can be used in field control programs, after conducting more studies on their effect on the soil and other environmental components.
\end{abstract}

Keywords: Massylaea vermiculata, Inorganic salts, Toxicology, Histology, LPO enzyme, Egg lying, Pest control

\section{Background}

Land snails cause damage to different kinds of plants causing great economic loss in nurseries, agricultural field, orchards, and greenhouses, in many parts of the

\footnotetext{
*Correspondence: soha_snails@yahoo.com

Agriculture Harmful Animals Research Department, Plant Protection

Research Institute, Agriculture Research Center, Dokki, Giza, Egypt
}

world (Bonnelly, 1965; Calabrese et al., 1977). In Egypt, the chocolate band snail, Massylaea vermiculata (O.F. Müller 1774) (Eobania vermiculata, The name was modified by Bouaziz-Yahiatene et al., 2017) is one of the most known pest species, widespread in several areas in ornamental, horticulture, and field crops (Shehata et al., 2009). Therefore, continued efforts are conducted to identify and test more effective molluscicides against this 
snail species. Many publications, about molluscicides' effect, are found in the literature. Most researches are restricted to investigate the toxicological effects against target snails. However, information about the biological effects, which helps in more understanding of their mode of action are still lacking (El-Bolkiny et al., 2000). Methomyl is usually recommended to be used as a molluscicide against land snails (Abo-Bakr, 1997). It is still the common compound usually used to protect crops from land snail's attack. For controlling land snails in agricultural fields, there should be more studies on new effective and safe materials for the environment (EL-Shahat et al., 2009; Abbas Nada, 2020).

Sodium benzoate is a widely used preservative in the food industry. It is used as an antifungal agent in juices and sweet products (Salkowski, 1975; Stanojevic et al., 2009). Sodium nitrate is also used to conserve fish and meat products, with an effective concentration of $0.02 \%$ (Noel et al., 1990; Stanojevic, et al., 2009). European commission limits for sodium benzoate is $0.5 \%(E C, 1995)$.

Inhibition of growth and activity of microorganisms can be achieved by lowering $\mathrm{pH}$ of medium, or by increasing the concentration of sodium nitrate or sodium benzoate (Restaino et al., 1981; Stanojevic et al., 2009). Sodium benzoate has decreased the cell line viability and induced both cell cycle arrest and toxic events indicating their high potential of being cytotoxic and genotoxic material (Aldwany Amal et al., 2018). LPO product accumulation in human tissues is a major cause of tissue and cellular dysfunction that plays a major role in aging and most age-related and oxidative stress-related diseases (Negere Anne et al., 2010).

The present work aims to study the biological and toxicological effect of sodium carbonate, sodium benzoate, and sodium nitrite against the chocolate band snails, Massylaea vermiculata, to expand the possibility for more effective damage control programs of this pest species in Egyptian agricultural fields.

\section{Methods}

\section{Tested compounds}

a. Inorganic salts. Three tested inorganic salts were used in this study i.e., sodium carbonate $\left(\mathrm{NaCO}_{3}\right)$, sodium benzoate $\left(\mathrm{C}_{7} \mathrm{H}_{5} \mathrm{NaO}_{3}\right)$, and sodium nitrate $\left(\mathrm{NaNO}_{3}\right)$. Each salt is a white powder $99 \%$, produced by Biochem for library chemicals.

b. Methomyl compound (Common name).

Trade name. Newmyl (20\% SL) is a carbamate insecticide recommended to be used The EMALR, as bait against land snail infestation in Egyptian Agricultural fields, at the rate of $8-10 \mathrm{~kg} / \mathrm{Fed}$. The $\mathrm{LD}_{50}$ value for rats is $17-24 \mathrm{mg} / \mathrm{kg}$. It was obtained from Kafr El-Zayat Company, Egypt.

\section{Experimental animals}

Adult individuals of chocolate band snails, Massylaea vermiculata were collected from citrus nursery at AbuRawash, Giza Governorate. Animals were transferred to the laboratory of the Plant Protection Research Institute, Agricultural Research Center. Animals were kept in small glass boxes $(55 \times 65 \times 40 \mathrm{~cm})$ containing moist soil (8-10-cm-high) and covered with a rubber band to prevent snails from escaping. Boxes were provided with fresh green lettuce and carrot slices. Calcium powder was spread on soil surface as a source of calcium, three times per week. Dead animals and detritus of rearing were daily removed.

\section{Laboratory experiments \\ Contact (thin layer film) technique}

The thin layer film technique was used according to Asher and Mirian (1981). Different concentrations of each tested inorganic salt were applied using water in a Petri-dish, (9-cm-diameter). Two $\mathrm{ml}$ of each concentration was spread on the inner surface of each Petri-dish, by moving the dish gently in circles. Water was evaporated under room conditions in a few minutes, leaving a thin layer film of each compound on the surface of the Petri-dish. Snails were exposed to the candidate concentration for one week (two snails/one Petri dish, and five replicates for each concentration). A parallel control test was conducted using plain water. Dead snails were daily counted and removed. Mortality percentages and $\mathrm{LC}_{50}$ values were determined according to Finney (1971).

\section{Effect of inorganic salts on egg-laying}

Snails were treated with $1 / 2 \mathrm{LC}_{50}$ of each tested inorganic salt i.e., $1.2,5.9$, and $4.8 \%$ for sodium carbonate, sodium benzoate, and sodium nitrate, respectively, using the thin layer film technique for one week. Three replicates were used (each of 20 animals) for each treatment. Animals were transferred in small glass boxes containing a mixture of sandy soil, clay soil, and patmos (1:1:1 ratio), and moistened with water three times a week, and kept in $20 \pm 2{ }^{\circ} \mathrm{C}$ and $80 \pm 5.0$ R.H\%. The cultural boxes were checked daily searching for clutches of eggs. Newly deposits clutches were removed with soil, placed in another box and observed daily until hatching to calculate the hatchability percentages (Hussein et al., 2005). 


\section{Effect of lipid peroxidase (LPO) activity}

LPO activity was measured, after seven days of treatment with $1 / 2 \mathrm{LC}_{50}$ of each tested compound compared with control using contact technique.

- Sample preparation.

After removing of snail shells, $1 \mathrm{~g}$ of snail tissue was homogenized for 3 min under cooling in a homogenizer with $10 \mathrm{ml}$ of sodium chloride $0.9 \mathrm{~N}$ per $1 \mathrm{~g}$ tissue and then centrifuged (4000 r.p.m. for $15 \mathrm{~min}$.). The enzyme activity was determined according to Ohkawa et al. (1979).

The obtained data were statistically analyzed by ANOVA and LSD at $(p<0.05)$ using the Costat program (COHORT, 2005).

\section{Histological studies}

The effect of $1 / 2 L_{50}$ of the three tested inorganic salts on the ovotestis tissues of treated $M$. vermiculata was studied after seven days of treatment comparing with untreated snails. Autopsy samples were taken from the ovotestis of treated and untreated snails, then fixed in $10 \%$ formol saline for $24 \mathrm{~h}$. Washing was done in tap water, and then serial dilutions of alcohol (methanol, ethyl, and absolute ethyl) were used for dehydration. Specimens were cleared in xylene and embedded in paraffin at 56 degrees in a hot air oven for twenty-four hours. Paraffin bee wax tissue blocks were prepared for sectioning at 4-microns-thickness by slide microtone. The obtained tissue sections were collected on glass slides, deparaffinized, and stained by hematoxylin and eosin stain for routine examination by light electric microscope (Banchroft et al., 1996).

\section{Field application}

Two inorganic salts, sodium carbonate, and sodium nitrite were tested as a spray compared with methomyl compound against Massylaea vermiculata on pomegranate nursery trees which planted in Nursery of the Agricultural Ministry, EL-Dokki district Giza Governorat. Eight plots were chosen (each of $50 \mathrm{~m}^{2}$ ), two replicates were used for each compound and others for control. At least two meters distance was kept between each plot and the other. Live snails were counted on random trees in each plot, pre- and post-treatment at 1, 3, 7, 15, and 21 days of treatment. The reduction in the snail population was calculated after 21 days of treatment according to the formula described by Henderson and Tilton (1952).

$$
\text { Population Reduction } \%=1-\frac{\mathrm{C}_{1} \times \mathrm{T}_{2}}{\mathrm{C}_{2} \times \mathrm{T}_{1}} \times 100
$$

$\mathrm{C}_{1}=$ Number of snails in control before application. $\mathrm{C}_{2}=$ Number of snails in control after application. $\mathrm{T}_{1}=$ Number of snails in treatment before application. $\mathrm{T}_{2}=$ Number of snails in treatment after application.

\section{- Statistical analysis}

Data Analysis, obtained data were analyzed as one way ANOVA, using Proc ANOVA in SAS software (Version 9.1; SAS Institute, Cary, NC, USA) (SAS Institute, 2008).

\section{Results}

\section{Laboratory studies}

Toxicity tests

Data in Table 1 show the efficacy of three tested inorganic salts on land snails, Massylaea vermiculata using contact technique after one week of treatment. The concentrations of sodium carbonate at $1,2,4,6$, and $8 \%$ caused 20 , $40,50,80$, and $90 \%$ mortality, respectively, while sodium benzoate achieved 10, 30, 50, and $70 \%$ mortality with 6 , 8,13 , and $15 \%$ concentrations, respectively. Farther more, sodium nitrite gave $10,20,40,50$, and $70 \%$ mortality at the rate of $0.5,2,8,13$, and $15 \%$, respectively. The $\mathrm{LC}_{50}$ values were $2.4,11.8$, and $9.6 \%$ for sodium carbonate, sodium benzoate, and sodium nitrite, respectively.

\section{Effect of the tested inorganic salts on egg production and hatching percentage}

The effect of the tested inorganic salts on the egg production of land snail, Massylaea vermiculata, shown in Table 2. Results indicated that sodium carbonate and sodium nitrite exhibited complete inhibition for egg

Table 1 Effect of three inorganic salts against land snail, Massylaea vermiculata, after seven days of treatment

\begin{tabular}{llll}
\hline Salt & $\begin{array}{l}\text { Concentration } \\
(\%)\end{array}$ & Mortality (\%) & LC $_{\mathbf{5 0}}$ (\%) \\
\hline Sodium carbamate & 1 & 20 & \\
& 2 & 40 & 2.4 \\
& 4 & 50 & \\
Sodium benzoate & 6 & 80 & \\
& 8 & 90 & 11.8 \\
Sodium nitrite & 8 & 10 & \\
& 13 & 30 & \\
& 15 & 50 & \\
& 0.5 & 70 & \\
& 2 & 10 & \\
& 8 & 20 & \\
& 13 & 40 & \\
& 15 & 50 & \\
\hline
\end{tabular}


Table 2 Effect of $1 / 2 L^{2} C_{50}$ of three inorganic salts on egg product of land snail, Massylaea vermiculata

\begin{tabular}{lllllc}
\hline Treatment & Concentration \% & $\begin{array}{l}\text { No. of egg masses } \\
\text { Mean } \pm \text { SE }\end{array}$ & $\begin{array}{l}\text { No. of egg in one } \\
\text { mass } \\
\text { Mean } \pm \text { SE }\end{array}$ & $\begin{array}{l}\text { No. of hatching in } \\
\text { one mass } \\
\text { Mean } \pm \text { SE }\end{array}$ & Hatchability \% \\
\hline Control & - & $16.7 \pm 1.5^{\mathrm{b}}$ & $96.5 \pm 0.4^{\mathrm{b}}$ & $93.6 \pm 1.7^{\mathrm{b}}$ & 96.9 \\
Sodium carbamate & 1.2 & 0.0 & 0.0 & 0.0 & 0.0 \\
Sodium benzoate & 5.9 & $3.1 \pm 0.0^{\mathrm{a}}$ & $16.6 \pm 2.1^{\mathrm{a}}$ & $13.6 \pm 1.1^{\mathrm{a}}$ & 81.9 \\
Sodium nitrite & 4.8 & 0.0 & 0.0 & 0.0 & 0.0 \\
\hline
\end{tabular}

Hatchability $\%=\frac{\text { No. of hatching in one mass }}{\text { No. of }} \times 100$

a Significant, ${ }^{\mathrm{b}}$ non significant at $p<0.05$

Table 3 Effect of $1 / 2 \quad L C_{50}$ of three inorganic salts on lipid proxidase (LPO) activity (nmol/ g) tissues in land snail, Massylaea vermiculata

\begin{tabular}{lllll}
\hline Control & Treatment & & & \\
\cline { 2 - 5 } & $\begin{array}{l}\text { Sodium } \\
\text { carbonate }\end{array}$ & $\begin{array}{l}\text { Sodium } \\
\text { benzoate }\end{array}$ & Sodium nitrite & LSD \\
\hline Mean $\pm \mathrm{SE}$ & Mean $\pm \mathrm{SE}$ & Mean $\pm \mathrm{SE}$ & Mean $\pm \mathrm{SE}$ & 5.6 \\
$2.5 \pm 0.6^{\mathrm{b}}$ & $11.9 \pm 2.3^{\mathrm{a}}$ & $15.3 \pm 1.9^{\mathrm{a}}$ & $4.2 \pm 1.6^{\mathrm{b}}$ & \\
\hline
\end{tabular}

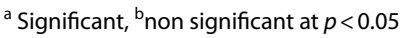

production in treated snails while sodium benzoate recorded $81.9 \%$ hatchability comparing with $96.9 \%$ for untreated snails. There was a significant difference in the fecundity of treated snails with sodium benzoate compared with control.

\section{Effect of tested inorganic salts on lipid peroxidase}

Data in Table 3 show the effect of the three tested inorganic salts on lipid peroxidase enzyme in $M$. vermiculata after 7 days of treatment. The results revealed that sodium carbonate and sodium benzoate achieved significant effects compared with control. Both compound caused a severe increase in the secretion of the enzyme as the level of the enzyme was increased from 2.5 to 11.9 and $15.3 \mathrm{nmol} / \mathrm{g}$ tissue for the two salts, respectively. While it slightly increased to $4.2 \mathrm{nmol} / \mathrm{g}$ tissue in case of sodium nitrite.

\section{Effect of three inorganic salts on ovotestis tissues of Massylaea vermiculata}

The histological effect on ovotestis of $M$. vermiculata treated with $1 / 2 L_{50}$ of the three tested inorganic salts (sodium carbonate, sodium benzoate, and sodium nitrite) is shown in Figs. 1, 2, 3, 4, and 5 after 7 days of treatment. Figure 1 showed the normal tissues of the ovarian structure with different follicular and ova in the untreated snails. Figure 2 showed the normal spermatozoal in the sac. Figure 3 showed necrobiotic changes in the ova, with the reduction in spermatozoal concentration in
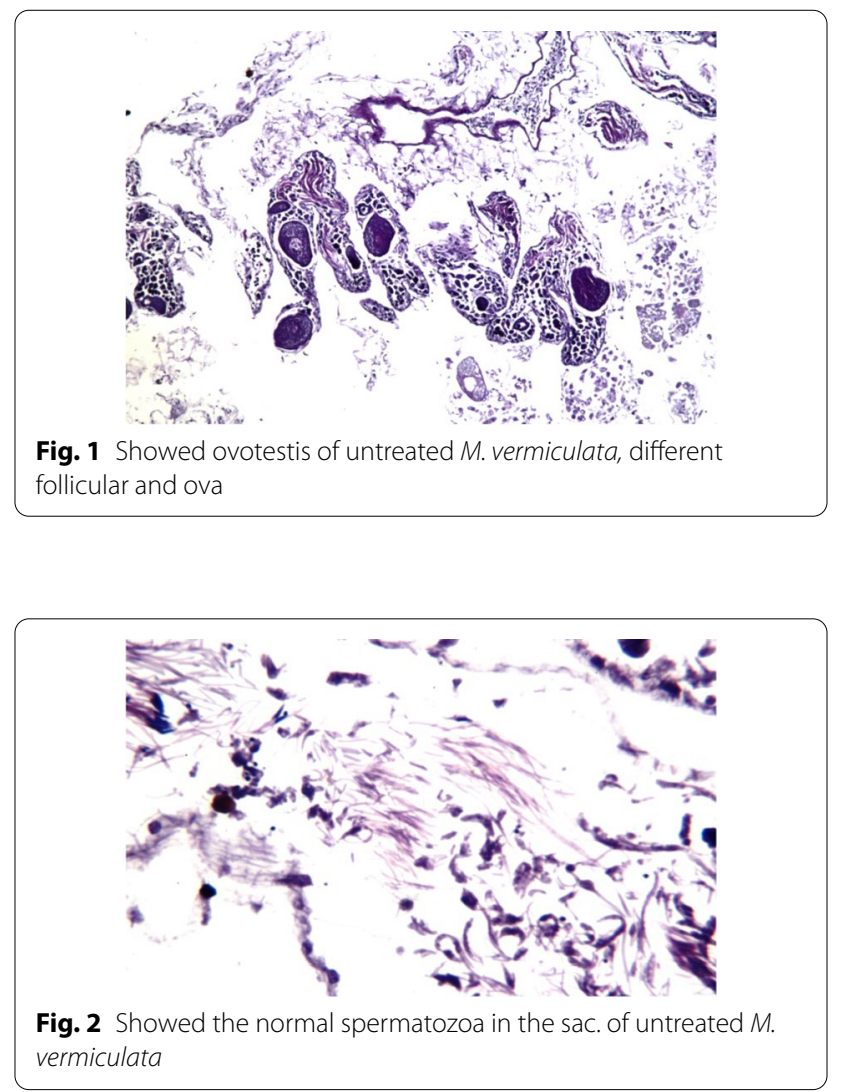

the ovotestis treated with sodium carbonate. Figure 4 showed no histopathological alteration in the ovarian while the spermatozoal showed diminished concentration after treatment with sodium benzoate, while Fig. 5 showed the effect of sodium nitrite which caused the same effect of sodium carbonate, whereas, it induced necrobiotic change in the ova with a reduction in spermatozoal concentration.

\section{Field studies}

The field performance of the two tested inorganic salts (sodium carbonate and sodium nitrate) compared with 


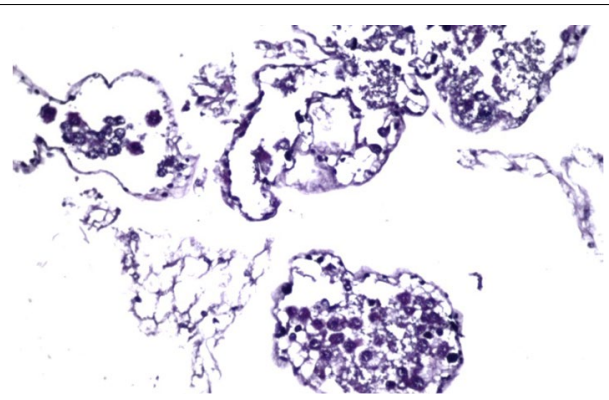

Fig. 3 Showed ovotestis of treated M. vermiculata with sodium carbonate. Necrobiotic change was detected in the ova and some follicles, associated with diminished in the spermatozoal concentration

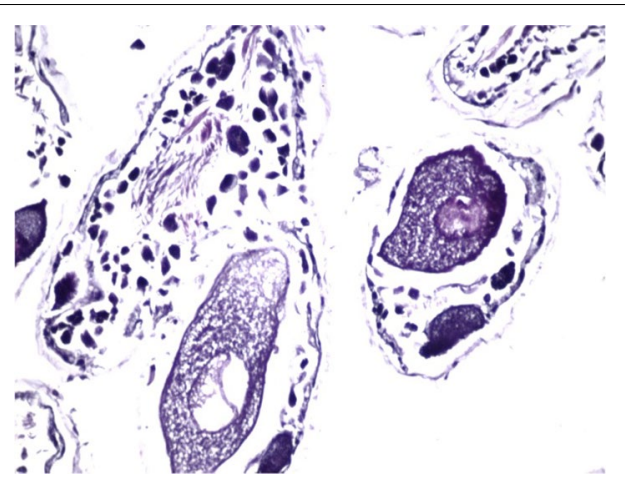

Fig. 4 Showed ovotestis of treated M. vermiculata with sodium benzoate. There was no histopathological alteration in the ovarian structure while the spermatozoa showed diminished concentration

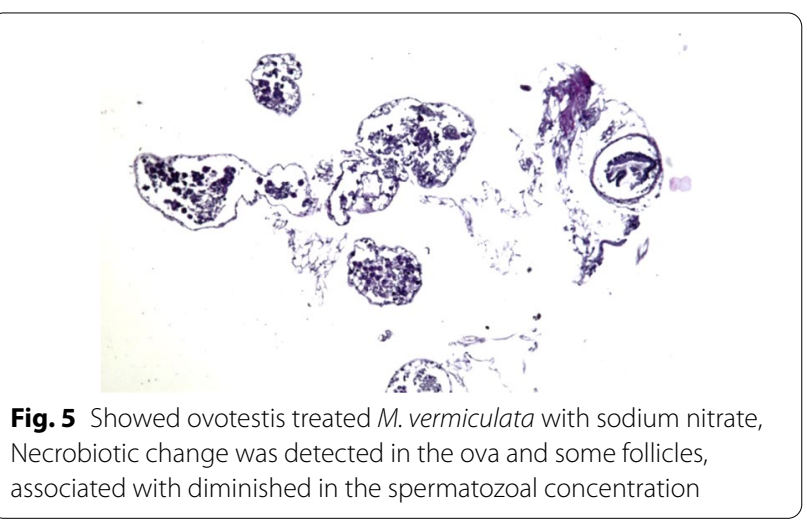

methomyl (recommended compound) against Massylaea vermiculata population is shown in Table 4 . The two tested inorganic salts achieved good result against land snail, $M$. verniculata, compared with the recommended compound. Results revealed that sodium carbonate and sodium nitrite caused 84.6 and $80.8 \%$ population reduction in snails, respectively, compared with $73.7 \%$ by methomyl compound.

\section{Discussion}

\section{Laboratory studies}

A gradual increase in the mortality percentage was observed with the increase in increasing concentration of the tested salts. Sodium carbonate was the most toxic salt against land snail, Massylaea vermiculata, followed by sodium nitrite and sodium benzoate. It was noticeable that inorganic salts extended a highly toxic effect after a long time of treatment. This result may be due to that these compounds take a long time arriving to the site of action in the treated snails' body. Corrao Norah et al. (2006) reported that $500 \mathrm{ppm}$ of nitrite gave low mortality against adult and juvenile snails till $96 \mathrm{~h}$ after treatment. The influence of adding chloride on nitrite enhanced toxicity against Cray fish, Orconectes limosus after 96 h (Dickinson, 2016; Kozak et al., 2005). Hegab et al. (2013) studied the effect of copper sulphate against Eobania vermiculata and found that 1,3,5, and 7\% concentrations caused $65,70,80$, and $85 \%$ mortality, respectively, after seven days of treatment. The juveniles of $E$. vermiculata were more sensitive to inorganic salts than adults (Hegab et al., 2013; Ismail \& Hegab, 2006). While Ismail et al. (2010) reported that copper hydroxide had a low effect against Monacha cartusiana under laboratory and field conditions.

The effect of the tested inorganic salts on land snail, M. vermiculata, egg production may be due to deformation in embryogenesis and losing embryos. Goddard and Martin (1966) recorded that hatching new snails were reduced after treatment with embactin benzoate. Moreover, Adewunmi et al. (1987) observed that the reduction in the glycogen and protein content leads to decreased egg production in Biomophalaria glabrata and Lymnaea columella. El-Bolkiny et al. (2000) found that $0.3 \mathrm{ppm}$ of Diethyldithiocarbamate caused inhibition in egg hatchability of Biomophlaria alexandrina after five days of treatment. Chauhan et al. (2011) reported that 20 and $40 \%$ Plant extract, Lantana indica against water snail, Lymnaea acuminate, reduced the fecundity and hatchability of snails. After 15 days of treatment with nitrite, the snail egg production was reduced compared with untreated snails (Cofone et al., 2020). Sharaby et al. (2008) found that inorganic salts as $\mathrm{ZnO}_{4}, \mathrm{KBr}, \mathrm{CuCl}_{2}$, $\mathrm{KOH}$, and $\mathrm{KI}$ gave $100 \%$ sterility against red palm weevil, Rhynchophprus ferrugineus. El-Sabagh Marwa et al. (2015) showed that inorganic salts $\mathrm{NaOH}, \mathrm{Ca}(\mathrm{OH})_{2}$, and $\mathrm{ZuSO}_{4}$ achieved $100 \%$ sterility against cotton leaf worm, Spedopatera littoralis, causing several malformations in the pupal stage. The effect of the three tested inorganic salts on lipid peroxidase (LPO) enzyme in M. vermiculata 
Table 4 Field Performance of two inorganic salts against land snail, Massylaea vermiculata, comparing with methomyl compound after 21 days of treatment

\begin{tabular}{|c|c|c|c|c|c|c|}
\hline \multirow[t]{2}{*}{ Tested compound } & \multirow[t]{2}{*}{ Concentration } & \multicolumn{2}{|c|}{ No. of snails before treatment } & \multicolumn{2}{|c|}{ No. of live snails after treatment } & \multirow{2}{*}{$\begin{array}{l}\text { Population } \\
\text { reduction } \%\end{array}$} \\
\hline & & Total & Mean \pm SD & Total & Mean \pm SD & \\
\hline Control & - & 247 & $24.7 \pm 9.3^{b}$ & 192 & $19.2 \pm 7.3^{b}$ & - \\
\hline Sodium carbonate & $80 \mathrm{~g} / \mathrm{L}$ & 338 & $33.8 \pm 11.1^{\mathrm{a}}$ & 40 & $4.4 \pm 1.6^{c}$ & 84.6 \\
\hline Sodium nitrite & $150 \mathrm{~g} / \mathrm{L}$ & 394 & $39.4 \pm 11.3^{\mathrm{a}}$ & 59 & $5.9 \pm 3.3^{c}$ & 80.8 \\
\hline Methomyl & $20 \mathrm{~mL} / \mathrm{L}$ & 234 & $23.4 \pm 2.2^{b}$ & 48 & $4.8 \pm 5.0^{c}$ & 73.7 \\
\hline LSD & & & & & 7.36 & \\
\hline
\end{tabular}

${ }^{\text {a }}$ Significant, ${ }^{\mathrm{b}}$ non significant at $p<0.05$

after seven days of treatment affected membrane fluidity association of biomolecules (membrane-bound proteins or cholesterol) with membrane and cell health (Halliwell \& Gutteridge, 2015). Lipid peroxidase is wildly used as a biomarker of oxidative stress as raising the level of oxidation causing severe damage to the enzyme in snail species (Barky et al., 2012; El-Shenawy et al., 2012; AlDaihan et al., 2010; Ali et al., 2015; Bhagat et al., 2016). Wang et al. (2014) reported that LPO enzyme increased in the digestive gland of Achtina fulica after treatment with broad-spectrum antimicrobial agent. The increase in LPO enzyme activity at high temperature is due to an increase in polyunsaturation in mitochondrial membrane leading to high mitochondrial respiration, with increase in the information of ROS (Bhagat et al., 2016). The same results of the histological effect on ovotestis of $M$. vermiculata treated with $1 / 2 \mathrm{LC}_{50}$ of three tested inorganic salts (sodium carbonate, sodium benzoate, and sodium nitrite) were obtained by Abbas Nada (2020) on ovotestis of $E$. vermiculata after being treated with an emamectin benzoate. The necrobiotic changes and reduction in spermatozoal concentration may be attributed to the tested inorganic salt, which causes mortality for snail sperms, and induced problems to the transport of sperms to the ova that prevent the production of new hatching. This result may be due to that the inorganic salts were absorbed by the reproductive system tissues. Xiao et al. (2000) reported that the lipophilic of botanical extracts affected membrane lipid, and changed permeability leading to water loss cause dehydration, and lead to abnormalities of egg laying. This may be due to the molluscicidal effect that destroyed the ova, by preventing formation and development. These results agreed with Zhou et al. (1993) clarifying that the niclosamide caused a reduction in the number of spermatozoal of Biomophalaria glabrata. Also, Mohamed et al. (2004) registered that Mepiquat chloride caused abnormal changes in the tissues of ovotestis glands in Biomophlaraia alexandrina. The same results were observed by Amaeze et al. (2011) they found that high concentrations of NPK fertilizers caused necrosis in the tissues of the genital organs of the land snail, Archachatina marginata. Dethiert (1955) and Frings (1946), indicated that inorganic salts are transported across the cell membrane, and their penetration was according to the order of ionic mobility which will determine the order of effectiveness. Moreover, the effect of inorganic salts may be due to salts ion accumulation in the snails' tissue after treatment, causing an impending effect on the viability of sperm and ovaries of snails.

\section{Field studies}

The two tested inorganic salts achieved good results against land snail, $M$. verniculata compared with methomyl. Abbas Nada (2020) reported that embactin benzoate and chitosan achieved $66.6 \%$ and $74.3 \%$ population reduction of snails, respectively, under field conditions. Mobarak Soha et al. (2021) indicated that clodinafoppropargyl caused $90.7 \%$ population reduction in the land snail, Helix aspersa, compared with $75.0 \%$ for methomyl, after 21 days of treatment. Ali (2017) reported that Round Up caused $17.2 \%$ population reduction of the land snail, Monacha cartusiana. Also, NPK fertilizer was examined by Eshra et al. (2016) under field conditions against Land snails, Monacha obstructa, it gave $66.8 \%$ population reduction after seven days of treatment. Samy et al. (2015) reported that methomyl reduced land snail, Monacha sp., population in cabbage and lettuce fields. Chen et al. (2019) evaluated the novel molluscicide PPUO7 (the mixture of Kaolin and black carbon 25\% PPUO7 WP) in the field against land snail, Oncomelania hupensis. They revealing that the molluscicidal effect at $2.0 \mathrm{~g} / \mathrm{m}^{2}$ provided $95 \%$ reduction in snails population.

\section{Conclusions}

From previous results, it is cleared that the three tested inorganic salts have a high toxic effect on the tested land snail, Massylaea vermiculata. They caused mortality and fertility reduction of live treated snails under laboratory 
conditions by inhibiting the egg production. Therefore, they can recommend to be used in land snail control programs in Egyptian agricultural fields. However, more future studies should be conducted on the effect of this inorganic salts on soil and other environmental components.

\section{Abbreviations}

LC $_{50}$ : Half Lethal Concentrations; LPO: Lipid Peroxidase Enzyme; SL: Soluble Liquid; EMARL: Egyptian Ministry of Agriculture and Land Reclamation; LD $_{50}$ : Half Lethal Dose; Kg/Fed: Kilogram per Feddan; rpm: Round per minutes; ANOVA: Analysis of Variance; LSD: Least significant difference; SAS: Statistical Analysis System.

\section{Acknowledgements \\ I wish to express my deepest gratitude to Dr. Abd El-Aziz Abou El-Ella Khedr Professor of Pesticides, Plant Protection Research Institute, ARC., for his gener- ous help and support. And I wish to express my deepest gratitude to Dr. Aly El-Sherbiny Professor of Vertebrate Ecology, in Harmful Animal Research Department, Plant Protection Research Institute, ARC., for correcting and for the manuscript's language, and for scientifically reviewing. Great and special thanks to Dr. Waheed Gabr, Professor in Harmful Animal Research Depart- ment, Plant Protection Research Institute, ARC., for correcting the manuscript scientifically. Great thanks to Dr. Randa Kandil assistant professor, Agriculture Harmful Animals Research Department, Plant Protection Research Institute, ARC., for analyzing the results statically.}

\section{Authors' contributions}

Not applicable. One author is executing the search. The author read and approved the final manuscript.

\section{Funding}

No fund, It is the personal effort of author.

\section{Availability of data and materials}

The data sets used and analyzed during the current study are available in this article, contain studies on animals (snails) performed by the author.

\section{Declarations}

\section{Ethics approval and consent to participate}

Regarding animals ethics approval by Plant Protection Research Institute, Agriculture Research Center, Giza, Egypt. This article does not contain any studies with human participants performed by the author.

\section{Consent for publication}

The author consent for publication.

\section{Competing interests}

The authors declare that they have no competing interests.

Received: 6 August 2021 Accepted: 31 October 2021

Published online: 27 November 2021

\section{References}

Abbas Nada, M. (2020). Effecacy of certain chemical control agents against land snails with special references to their physiological effects. PhD.Thesis Fac., of Agric., Cairo Univ. 2 pp.

Abo-Bakr, Y. (1997). Toxicological and environmental studies on some terrestrial gastropds. MSc. Thesis fac. Agric., Alex. Univ., 2 pp.

Adewunmi, C., Thueu, P., \& Madsen, H. (1987). Studies on aridarin, Tetrapleura tetraptera Potential plant molluscicides: The effect of sub lethal concentrations of aridarin isolated from T. tetraptera and hayluscide on Biomphalaria glabrata and Lymnaea collumella. In Proceedings of the international Conference on Schistosomiasis. Rio de Janeiro. October 26-30p.
Al-Daihan, S., Kaggwa, J., \& El-Ansary, A. (2010). The effect of sublethal concentration of Solanum nigrum on some antioxidants in Biomphalaria Arabica. Journal of the Egyptian Society of Parasitology, 40, 205-214.

Aldewany Amal, Z., Basal Wesam, T., Al senosy Neima, K., \& Issa Alia, M. (2018) Evaluation of cytotoxicity cell cycle perturbations and Apoptotic indication in human normal and cancer liver cell lines exposed to potassium nitrite and sodium benzoate. Egyptian Academic Journal of Biological Sciences B Zoology, 10(1), 105-118.

Ali, D., Ahmed, M., Alarifi, S., \& Ali, H. (2015). Ecotoxicity of single-wall carbon nanotubes to fresh water snail Lymnaea luteola L. Impacts on oxidative stress and genotoxicity. Environmental Toxicology, 30, 674-682.

Ali, M. (2017). Comparison among the toxicity of thymol and certain pesticides on adult survival and egg hatchability of glassy clover snail Monach cartusiana. Journal of Plant Protection and Pathology, 4, 189-194.

Amaeze, N., Ugwoeje, D., \& Engonwamn, R. (2011). Histopathological and physiological effects of selected agrochemical on non target Archaetina margrinata. Yectivenscys, 2, 21-26.

Asher, R. S., \& Mirian, F. (1981). The residual contact toxicity of Bay Sir 8514 to Spodoptera littoralis larva. Phytoparasitica, 9(2), 133-137.

Banchroft, J., Stevens, A., \& Turner, D. (1996). Theory and practice histological techniques (4th ed.). Churchil Livingston.

Barky, F., Abdelsalam, H., Mohamoud, M., \& Hamdi, S. (2012). Influnce of Atrazine and round up pesticides on biochemical and molecular aspects of Biomphalaria alexandrina. Snails. Pesticide Biochemistry and Physiology, 104, 9-18.

Bhagat, J., Ingole, B., \& Singh, N. (2016). Glutathione S-transferase, catalase, superoxide dismutase, glutathione peroxidase, and lipid peroxidation as biomarkers of oxidative stress in snails. A Review., 13, 336-349.

Bonnelly de Calvent, I. (1965). Copper poisoning in snail Helix pomatia and its effect on mucus secretion. Annals of New York Acadaemy of Science, 118, 1015-1020.

Bouaziz-Yahiatene, H., Pfarrer, B., Medjdoub-Bensaad, F., \& Neubert, E. (2017). Revision of Massylaea Möllendorff, 1898 (Stylommatophora, Helicidae). Zoo Keys, 694, 109-133.

Calabrese, A., Thurbuerg, F., \& Gould, E. (1977). Effects of calcium, Mercury, and silver on marine animals. Marine Fisheries Review, 39, 5-11.

Chauhan, S., Shahi, J., \& Singh, A. (2011). Eco- Friendly management of Lymnaea acuminate, snail vector of fascioliasis in livestock in eastern Ultar Paradesh. Global Veterinarian, 1, 10-18.

Chen, A., Bookstein, J., \& Meldrum, D. (2019). Diagnosis of atetosterone secreting adrenal adenoma by selective venous Catheterization. Fertility and Sterility, 55, 1202-1203.

Cofone, R., Federica, C., Tersa, C., Giovanni, L., Antonetta, S., Carmela, G., Nieola, M., Macro, G., \& Ida, F. (2020). Massylaea vermiculata as a potential indicator of nitrite contamination in soil. Ecotoxicology and Environmental Safety, 204, 1-8.

COHORT software. (2005). Costat program, 6311.780 Light house, ave. PMB 320 Monterey, CA, USA

Corrao Norah, M., Darby, Ph., \& Pomory, C. (2006). Nitrite impacts on the Florida apple snail, Pomacea paludosa. Hydrobiologia, 568, 135-143.

Dethiert, V. (1955). The physiology and histology of the content chemo receptors of the blowfly. Quarterly Review of Biology, 30, 331-348.

Dickinson, D. (2016). Influence of chloride on the chronic toxicity of sodium nitrite to Ceriodaphnia dubia and Hyalella azteca. Ecotoxicology, 25, $1406-1416$.

EC. (European Commission). (1995). Eueopean Union Directive 95/ 2/ CE from 20.02 on food additives colorants sweeteners.

El-Sabagh Marwa, M., Desoky Shimaa, M., \& Ahmed Yasmein, E. (2015). Using certain inorganic salts as a chemosterilant against Spedopatera littoralis. Egyptian Academic Journal of Biological Sciences A Entomology, 8(2), 97-102.

El-Shahat, M., Eshra, E., Mesbah, H., \& Emtiaz, C. (2009). Toxicity of certain copper fungicides and other pesticides to terrestrial snails. Journal of Agricultural Sciences Mansoura University, 3(5), 5501-5507.

El-Shenawy, N., Mohammadden, A., \& Al- Fahmie, Z. (2012). Using the enzymatic and non enzymatic antioxidant defense system of the land snail Massylaea vermiculata as biomarkers of terrestrial heavy metal population. Ecotoxicology and Environmental Safety, 84, 347-354.

El-Bolkiny, Y., Rizk, E., Ansary, A., \& A. (2000). Effect of Diethyldithiocarbamate on some biological and physiological parameters of Biomphalaria alexandrina snails. Egyptian Journal of Aquatic Biology and Fisheries, 4(2), 157-181. 
Eshra, E., El-Deeb, H., \& Shaat, M. (2016). Laboratory and field evaluation of new fort as chemical fertilizer against some land snails. Egyptian Scientific of Pesticides, 1, 37-41.

Finney, D. J. (1971). Probit analysis (3rd ed.). Cambrige Univ. Press.

Frings, H. (1946). Gustatory thresholds for soucrose and electrolytes for the cockroach Periplanata americana (Linn). Journal of Experimental Zoology, 102, 23-50.

Goddard, C., \& Martin, A. (1966). Carbohydrate metabolism. In K. Wilbur \& C. Young (Eds.), Physiology of molluscs (Vol. 2, pp. 275-308). New York: Academic Press.

Halliwell, B., \& Gutteridge, J. (2015). Free radical in biology and medicine. Oxford Univ. Press.

Hegab, A., Arafa, A., \& Hilmy, A. (2013). Effecacy of methomyl and copper sulphate against Massylaea vermiculata (Müller) and Helicella vestalis (Preiffer) snail under laboratory and field conditions. Annals of Agricultural Science, Moshtohor, 51(3), 271-275.

Henderson, C., \& Tilton, W. (1952). Tests with acaricides against the brown wheat mite. Journal of Economic Entomology, 1(2), 157-161.

Hussein, A., Abu- Bakr, Y., Kassem, F., Al-Deeb, H., \& Abdallah, E. (2005). The sublethal effects of certain pesticides on reproductive performance of the land snail, Theba piasana. Egyptian Journal of Agricultural Research, $8(1), 261-270$

Ismail, Sh., \& Hegab, A. (2006). Response of juveniles and adults of brown garden snail Massylaea vermiculata (Müller) to certain chemicals. Egyptian Journal of Applied Science, 21(8), 30-38.

Ismail, Sh., Shataia, S., \& Smah Abdel-Kader, M. (2010). Effect of neem extract, Neemazoal on two land snail species under laboratory condition. Journal of Plant Protection and Pathology Mansoura University, 1(10), 799-806.

Kozak, P. Machova, J., \& Policar, T. (2005). The effect of chloride content in water on the toxicity of sodium nitrite for spiny- cheek crayfish Orconectes limosus (Raf). Bull Fr Peche Pestici, 376-377, 705-714.

Mobarak Soha, A., El-Abd Nema, M., \& Kandil Randa, A. (2021). Effect of clodinafop- propargyl compound against land snail Helix aspersa under laboratory and field conditions. International Journal of Agricultural Extension, (in press).

Mohamed, A., Bakry, F., \& Heba, F. (2004). Effect of abamectin as a molluscicide on survival fecundity and cercarial shedding of the fresh water snail Biomphalaria alexandrina infected with Schistosoma mansoni. In First Inter. Conf. Biol. Sci. Fac. of Sci. Tanta Univ., Vol. 1, pp. 207-216.

Negere, A., Nathalie, A., Victoria, A., \& Huveyda, B. (2010). Pathological aspects of lipid peroxidation. Free Radical Research., 44(10), 1125-1171.

Noel, P., Briand, E., \& Dumont, J. (1990). Role of nitrite in flavor development in uncooked crude meat products. Sensory assessment. Meat Science, 28, $1-8$.

Ohkawa, H., Ohishi, W., \& Yagi, K. (1979). Assay for lipid peroxides in animal tissues by thiobarbituric acid reaction. Analytical Biochemistry, 95, 351.

Restaino, L., Komateu, K., \& Syracuse, M. (1981). Effects of acids on potassium sorbate inhibition on food related microorganisms in culture media. Journal of Food Science, 47, 134-143.

Salkowski, E. (1975). Zur Kentniss der Kobragift aktivierenden Substancen. Berl Klin Wochenshr, 12, 297-298.

Samy, M., Fakharany, S., \& Hendawy, A. (2015). Population fluctuation and host perferenceof land snail Monacha sp.and its control of biocides compared with newmyl. In 5th Intern. Comp. plant Protec. Res. Instit. Hurgada. Egypt 3-9 May 2015. Sustainable Agricultural Development the agricultural Production and the challenge of plant protection.

SAS Institute. (2008). SAS/STAT 9.1 user's guide: The REG procedure (Book Excerpt). SAS Institute.

Sharaby, A., Al- Hwary, F., \& Ibrahim, S. (2008). Some inorganic salts for production of sterile adults of the red palm weevil, Rhynchophorus ferruginous (Coleptera: Curculionidae). Egyptian Academic Journal of Biological Sciences, 1(2), 205-210.

Shehata, S., Ismail, Sh., \& Samah Abdel-Kader, M. (2009). Survey, population dynamic, and important value of certain land snail species infesting different crops in Sharkia Governorate. Egyptian Academic Journal of Biological Sciences B Zoology, 1, 37-43.

Stanojevic, D., Comic, L., Stefanovic, O., \& Sukdolak, S. (2009). Antimicrobial effects of sodium benzoate, sodium nitrite and potassium sorbat and their sysynergistic action in vitro. Bulgarian Journal of Agricultural Science, 15(4), 307-311.
Wang, X., Liu, Z., Wang, W., Yan, Z., \& Zhang, C. (2014). Assissment of toxic effects of triclosan on the terrestrial snail, Achtina fulica. Chemosphere, $108,225-230$

Xiao, S., Peter, J., \& Marcel, T. (2000). Artemether an effective and agent for chemo prophylaxis against Shitosomiasis in China. Its in vivo effect on the biochemical metabolism of the Asian Shitosome. Southeast Asian Journal of Tropical Medicine and Public Health, 3(4), 724-732.

Zhou, X., Upatham, E., Kruatrachue, M., \& Sretarugsa, P. (1993). Effect of niclosamideand Eucalyptus on Biomaphalaria glbrata the intermediate host of snail. Journal of the Science Society of Thailand, 19, 117-128.

\section{Publisher's Note}

Springer Nature remains neutral with regard to jurisdictional claims in published maps and institutional affiliations.

\section{Submit your manuscript to a SpringerOpen ${ }^{\circ}$ journal and benefit from:}

- Convenient online submission

- Rigorous peer review

- Open access: articles freely available online

- High visibility within the field

- Retaining the copyright to your article

Submit your next manuscript at springeropen.com 